\section{Positions Available}

\section{POSTDOCTORAL RESEARCH ASSOCIATE \\ Oklahoma State University}

A position is available to conduct materials research on the preparation and characterization of novel photonic media. The applicant will work independently on conducting spectroscopic studies associated with (a) solidstate materials characterization and/or (b) thin-film deposition processes using pulsed laser sources. A PhD degree is required in physics, chemistry, or materials science. Applicant must also have experience in the following areas: nonlinear optics; optical characterization of electronic processes in nanodimensional semiconductor particles and in organic chromophores; operation of psec laser sources and streak cameras; ultrafast luminescence studies; time- and frequency-domain optical phase conjugation; and degenerate-, nondegenerate-, and time-delayed four-wave mixing methods.

Send CV and three letters of reference to:

Dr. Edward T. Knobbe

Department of Chemistry and the

University Center for Laser Research

320 Physical Sciences 1

Stillwater, OK 74078-0447.

OSU is an equal opportunity employer.

Classified Ads can be E-mailed to kaufold@mrs.org.
ACCESS THE

MATERIALS RESEARCH SOCIETY WEBSITE

\author{
http://www.mrs.org/related/materials.html \\ for links to the following Materials \\ Information and Databases:
}

- Atomic and Plasma Physics Databases from the Weizmann Institute

- ChemWeb

- CS ChemFinder - Search for Chemical Compounds on the WWW

- Electronic Structures Data Systems (Japan Science and Technology

Corporation) - Includes a Java Periodic Table

- Materials Properties for MEMS

- MatWeb - Online Materials Information Resource

- Materials Properties at New Mexico State University

- Materials Science Data at MIT

- National Nuclear Data Center at Brookhaven National Lab

- Particle-Surface Resources on the Web

- Polymers DotCom - Polymers related information

- Table of Isotopes at LBL

- X-ray Interactions with Matter page at LBL

- XPS International (Digital XPS Database Systems and Libraries)

If you have a link you feel should be added to this page, please contact the MRS webmaster (webmaster@mrs.org) and provide the necessary information.

\title{
POSTERMINARIES
}

\section{Library Materials Materials}

Try this: Crank up your favorite webbrowser, tune into a search engine (or even a meta-search engine), run a search on "materials" and see what turns up. If you prefer a ruder shock, do this using the search engine on the archive of a major newspaper. Expecting metals, semiconductors, polymers, ceramics, and the like? Guess again. MRS members tend to have a pretty clear idea about what materials are, but most of the information providers of the cyberworld seems to think that they are things that libraries have in their collections, or that are stored in those modern equivalents of libraries: websites. The latter will provide the subject matter of almost all of your newspaper-site hits; and I don't want to write about the kind of materials involved-at least not in this publication.

Married to a librarian as I am, I have known for a long while that my subject's title is ambiguous to a large part of the population. If you go to your local university's Library School (which may now be called a School of Information Science, or even Informatics) and tell people that you are a materials scientist, they will assume that you engage in arcane studies of library collections.

For the time being, I have the upper hand at home-at least on this issue. The stuff I work on is referred to as "materials" while my wife works with "library materials." When she is at work, though, I am sure they are just "materials" for her, too. Let's try to keep this much clear: The readers of this magazine deal with "real" materials. The use of the same word for the stuff in the library is only a metaphor, but this may be a losing battle. Every first-year college student gets some formal introduction to the library and its materials but only a very few get an introduction to our kind. If you control the language you control the hearts and minds of the people.

Libraries have come a long way, just as materials science has. The majority of the information in today's library is not contained in books, but in other library materials including microfilm, microfiche, electronic media, maps, images in various forms, music recordings, etc. Let's not get 
started on the stuff in special collections. Indeed, the term library materials has become somewhat ambiguous, sometimes referring to the content and sometimes to the container. When the containers were exclusively books, it was quite clear what was meant by the term materials, but now a wondrous range of different media resides in the library, including "multimedia." (Would that be a library composite material, or a composite library material?) Music librarians now employ a synecdoche for a metaphorical material that is thereby transformed into a real material: Their older collections of musical performances are referred to as "vinyl." Who can keep up with linguistic double-twists like that? In the library, vinyl isn't always the stuff the collection is made of.

Of course, you can recognize the impact of the materials scientist in creating many of the physical manifestations of the new media-the library materials materials, if you like. What is less widely known is the direct role played by materials science in creating a set of library materials, in the "content" sense, that is almost completely media-independent. Project Gutenberg is an ongoing program that seeks to make electronic versions of literary texts available via the Internet. It was created in 1971 when someone at the Materials Research $\mathrm{Lab}$ at the University of Illinois (UrbanaChampaign) gave some computer time and an allocation of memory to a Michael Hart. (You can read all about it at http:/ / www.promo.net/pg/history.html/, right after you finish searching out materials citations.) Hart began creating ASCII files of major literary works, which are accessible to readers and researchers using almost any computer technology. This is arguably responsible for a rash of computer-based analyses of the "great works" that provided doctoral dissertation topics for a generation of graduate students in literature. Hart's stroke of genius (or possibly of ignorance, or maybe just the path of least resistance) was choosing to store his texts on a mainframe computer's hard disk system. This made them readily readable and transmissible, which is what distinguishes Project Gutenberg from a number of similar efforts. How many of us have data archived on eight-inch floppy disks for which we have no disk drive or operating system? (How many of you have even seen an eight-inch floppy?) And how many five-and-a-quarter-inch drives have you available, and how many disks with old source codes and inaccessible data on them? How much longer will three-and-ahalf-inch disks last now that zip ${ }^{\mathrm{TM}}$ and jazz $^{\mathrm{TM}}$ drives are increasingly supplied as standard equipment on PCs? Technology plows inexorably onward, leaving obsolescence in its wake; and heaven help all those of us who fail to convert their old data files to new formats. We materials scientists should be as aware of this as anyone-let us not forget that we are responsible for many of the advances in memory technology.

The librarians have faced this problem ahead of us. They embraced new technology early on, and always for the same reasons that drive us to work to increase data density now. The earliest known library was founded by Alexander the Great, at Alexandria, in Egypt, and the library materials of that day seem to have been clay tablets. What an advance papyrus must have been! What a huge savings of weight, readability, transportability...I just bet there were plenty of naysayers back then, complaining of the impermanence of the new format. Some centuries later as libraries began to fill up and their floors buckle under the weight of books made of paper (another advance), various microforms (starting with microprint, microfilm, and microfiche) promised to solve the storage problem, albeit at the expense of requiring some new machines. Libraries now struggle with the problem of keeping a range of incompatible and obsolete microform readers operational until the materials can be converted into some new format. And today librarians struggle with everwidening arrays of computer-based storage options, with ever-shortening preobsolescence half-lives. Imagine, if you will, the frustrations to be faced by postapocalyptic archaeologists, trying to decipher the stored writings of our civilization. Someone should try to prepare some kind of Rosetta Stone for them-and maybe for us, too. Think carefully about what materials it should be made of, and what materials it should contain!

Libraries are, at least in part, dedicated to long-term information maintenance, so it is hard for librarians to come to terms with the disposability of technology. Those that overcome this mental hurdle do so at some risk to their own welfare. Kenneth Dowlin, the head of the San Francisco public library was forced out of his job after the opening of a new Main Library in which, in the eyes of some of the trustees, computers took too great a prominence relative to books (San Francisco Chronicle, Jan. 22, 1997).

Project Gutenberg has transcended all of this and continues to grow at a rate of several titles a month. It seems, by whatever lucky accident, to have hit upon the right solution. Perhaps it was just the right idea at the right time: If you remember the computers of the early 1970s, you will recall that they were good number-crunchers and good at storing restricted kinds of data so long as it was either binary or ASCII. Graphics, complicated character sets, and GUIs were still rudimentary if available at all. Take a look at an image-simulation program from this era to see the lengths to which people would go to print gray-scale images on IBM line-printers. In this environment, it made little sense to attempt much storage of the scientific materials traditionally found in books and journals; and today we are still barely on the threshold of computerizing this kind of information. On the other hand, a nice book of words with no pictures or equations was just the right kind of thing to feed into a computer in 1971. If the technology had been just a little more advanced in its capabilities, maybe Project Gutenberg would have been supplanted by some more ambitious datastorage project that would probably have become obsolete in short order. A great deal is to be said for using the right tool for the job, and just as much for finding the right job when you obtain a new tool. Many are the plumbers who owe their income to a general failure of householders to understand this.

Well, if you are still reading this, you are probably doing so in a traditional printed medium, and it seems to me that books are an especially effective way of storing and transmitting information. They require no special reader hardware (save a moderately educated human; maybe a pair of spectacles). They are not volatile. They require no energy input to extract data from them and are therefore not sensitive to failed batteries, power surges, magnetic fields, etc. They are not threatened by millennium-year bugs, though certain species of cockroach do enjoy the older glues used by traditional binderies. (These bugs are readily avoided by the simple practice of taking the books off the shelf and reading them: $A$ contrast with computer bugs and viruses, which depend upon the use of the material in order to proliferate.)

Finally, it is interesting that one of the librarianship specialties in greatest demand today is preservation. The preservation librarian fights off the effects of time and the elements just as do many materials scientists, and although most of these professionals are trained in library schools, their work is very much materials science in the most real sense. I wonder: In what form do they store the results of their research?

ALEX KING 